\title{
EDITORIAL
}

\section{ORTHOGERIATRICS AND HIP FRACTURES}

\author{
A.M. SANFORD ${ }^{1}$, J.E. MORLEY ${ }^{1}$, A. MCKEE ${ }^{2}$
}

\begin{abstract}
1. Division of Geriatric Medicine, Saint Louis University School of Medicine, Saint Louis, Missouri, USA; 2. Division of Endocrinology, Saint Louis University School of Medicine, Saint Louis, Missouri, USA. Corresponding author: John E. Morley, MB,BCh, Division of Geriatric Medicine, Saint Louis University School of Medicine, 1402 S. Grand Blvd., M238, St. Louis, MO 63104, Email: john.morley@health.slu.edu
\end{abstract}

Approximately $14 \%$ of women and $6 \%$ of men will have a hip fracture during their life time (1). There is large geographical variation in hip fractures with the highest rates occurring in Scandinavian countries (over 500/100,000 annual age-standardized incidence) and the lowest rates in African countries (less than 100/100,000 age-standardized incidence) (2). In the United States, rates of hip fracture vary between 143 to $316 / 100,000$ for Caucasians and 76 to $136 / 100,000$ for persons of African origin.

Death rates after a hip fracture are quite high and are $10 \%$ at 10 days and 17 to $36 \%$ at 1 year (3). Not only do hip fractures confer high mortality rates, but the morbidity rates are quite staggering as well. One year after a hip fracture, $10 \%$ of patients are bedfast, $16 \%$ of patients are in a nursing home and $80 \%$ of patients require a walking aid that was previously unneeded. These poor outcomes have suggested the need for a focus on improving hip fracture care in older persons.

One approach to improving care of older persons with hip fracture is the collaborative approach of a closely cooperative team of a geriatrician and an orthopedic surgeon--often called orthogeriatrics. The first orthogeriatric unit was developed by Michael Devas (an orthopedist) and Robert Irvine (a geriatrician) in 1963 (4). In 1980, Richard Lefroy published the positive results of a combined unit in Western Australia on management of hip fractures (5). Adunsky et al (6) found lower mortality rates for patients who were admitted to a comprehensive geriatric hip fracture unit compared to standard care. Recently, a large prospective trial showed that these positive benefits extended to well after discharge and that patients with hip fractures had better mobility 4 months after hospitalization when receiving comprehensive care (7). A metaanalysis of 18 studies which included a total of 9094 patients of orthogeriatric collaboration found a significant reduction in mortality in hospital $(0.60 ; 6.42-6.84)$, long term mortality $(0.83 ; 0.74-0.94)$ and a reduction in length of stay (8).

\section{Operative Management}

Persons who do not have surgery for their hip fracture have four times the risk of death in the first year $(9,10)$. These deaths stem from complications of immobility and are often the result of deep vein thromboses, pulmonary emboli, pneumonia, and pressure ulcers. Those patients who mobilize out of bed quickly after their fracture despite not receiving operative management do somewhat better (11). It is typically

Received December 28, 2017

Accepted for publication December 28, 2017 recommended that patients who are able to undergo surgical intervention, even if of higher cardiac risk, should do so rather than electing for non-operative management. Hip fracture surgery can be viewed as a palliative procedure with the goal of achieving pain control in those patients who are nonambulatory at baseline.

Intuitively, low surgeon volume is associated with a longer length of stay and higher mortality (12). One key to favorable surgical outcomes is reducing the time it takes for the patient to undergo surgery, with recommendations that surgery should occur within 48 hours of when the fracture occurred $(13,14)$. Furthermore, recent studies have suggested that surgery within 6 hours of the time of fracture reduces postoperative mortality (15). The HIP ATTACK trial is attempting to confirm that accelerated time to surgery ( $<6$ hours) truly improves outcomes (NCT02027896).

Anemia in hip fracture patients is quite commonplace in the perioperative period because the arteries providing the blood supply to the femoral head are often torn, resulting in significant bleeding. Many patients will require a blood transfusion in the perioperative period. However, one study did show that a liberal blood transfusion strategy post hip fracture did not reduce mortality or 60 day independent walking (16). It may improve long term function in persons with dementia (17).

Pain control in the perioperative period is imperative in order to improve both the quality of life of the patient and to encourage early mobilization. It is recommended that most patients be placed on scheduled pain medication postoperatively. Additionally, there is some evidence that patients who have femoral nerve blocks done on admission and then having a continuous fascia iliac block placed have less pain and better walking and stair climbing ability throughout their hospital stay and at 6 weeks post-hospital discharge $(18,19)$.

\section{High Risk Populations}

Populations at high risk for increased morbidity and mortality following a hip fracture include those with multimorbidity, frailty and protein energy malnutrition. A correlation between comorbidity at discharge and poor functional outcomes has been demonstrated (20). Persons with the physical frailty phenotype have an increased risk of fractures in general and poor surgical outcomes $(21,22)$. A rapid screen for the physical phenotype for frailty - the FRAIL scale has been developed (23-27). Gleason et al (28) has shown that those deemed "frail" 
using the FRAIL scale had increased lengths of hospital stay, increased surgical complications, and were more likely to discharge to a nursing home following hip fracture. There are a number of treatable causes of frailty including polypharmacy, depression, sleep apnea, hypothyroidism, and sarcopenia and these should be assessed and screened for in hip fracture patients in the orthogeriatric unit (29).

Loss of muscle loss is a common occurrence in older persons and may contribute to falls and increased risks of hip fracture $(30,31)$. Sarcopenia is currently defined as poor function (measured by decreased walking speed or grip strength), associated with a low muscle mass (32-35). When screening for sarcopenia, it is important that cutoff points are defined based on ethnicity (36). A rapid screen for sarcopenia - SARC-F - has been developed (37-40) and can be used by primary care physicians to make an ICD-10 diagnosis of sarcopenia $(41,42)$. Loss of bone mass (osteoporosis) typically occurs concurrently with loss of muscle mass (sarcopenia), resulting in sarco-osteoporosis), and leading to an increase in the rate of hip fracture (43-45). It is important that the presence of sarcopenia be identified so that there can be an emphasized focus on resistance exercise in the acute rehabilitation unit following hip fracture (46).

Diabetic patients have a higher risk of sustaining hip fractures despite having greater bone densities (45). Part of this increase of fracture is due to overall poorer bone quality in diabetic patients, causing increased weakness and decreased integrity in the bone structure (47). In addition, individuals with diabetes mellitus are much more likely to be sarcopenic and have an increase in falls, conferring a higher hip fracture incidence $(48,49)$.

Protein energy malnutrition is a common problem in older persons and can accelerate the development of sarcopenia and frailty (50). The MiniNutritional Assessment (MNA) is a commonly used assessment tool for undernutrition (51-53). Both the malnutrition and weight loss are associated with severe functional impairment following hip fracture (54-56) because of interference with bone and wound healing and also the ability to regain an ambulatory status. Weight loss from anorexia of aging needs to be distinguished from weight loss due to cachexia because anorexia has treatable components (5760). Cachexia, however, is more difficult to correct because it stems from a catabolic process, in which the underlying causes are not always apparent or treatable. Anorexia, which is a major predictor of future weight loss, can be identified by the Simplified Nutrition Appetite Questionnaire (SNAQ) (61, 62). This should be done prior to hospital discharge in hip fracture patients so that targeted interventions can be put in place to reverse the weight loss or prevent more weight loss from occurring.

\section{Delirium}

Delirium is one of the most common complications following hip fracture and occurs in 10 to $65 \%$ of patients (6365). The diagnosis of delirium can be made using the Confusion Assessment Methodology (CAM) with particular attention of the patient's ability to focus or to maintain attention (66). The hyperactive motor subtype of delirium occurs almost twice as often as the hypoactive, but hypoactive delirium is often underdiagnosed (67). Median duration of delirium is 3 days and those with delirium often require longer hospital stays. Delirium in hip fracture patients without a diagnosis of dementia predicts higher one year mortality (68). Furthermore, a meta-analysis has confirmed that delirium in persons with hip fracture is associated with an increase in mortality and institutionalization (69).

The pathophysiology of delirium following hip fracture is uncertain and likely quite multi-factorial. Persons with protein energy undernutrition are more likely to develop delirium (70) as are those with underlying dementia. It is well-recognized that anticholinergic burden is commonly associated with delirium and medicines with inherently high anticholinergic activity should be stopped wherever possible $(70,71)$. Similarly, potentially inappropriate drugs delay full functional recovery following hip fracture (72). There is some evidence to suggest that C-reactive protein and inflammatory cytokine levels are elevated in the cerebrospinal fluid of persons who develop delirium following hip fracture surgery, but the significance of this finding is unknown (73). There is reasonable quality evidence that comprehensive geriatric evaluation and orthogeriatric management reduces delirium in persons with hip fracture $(74,75)$. Of note, antipsychotics should not be used to treat delirium (76) as they only target a small pathway implicated in the pathogenesis of delirium and are dangerous medications to use in the elderly.

\section{Infections}

Infections are the most common postoperative complication in persons with hip fracture (77). The most common infections are surgical site, pneumonia and urinary tract infection. To prevent surgical infections where possible patient risk factors should be modified, surgical procedures should be as short as possible and performed under optimal conditions and antimicrobial prophylaxis (cefazolin and vancomycin or clindamycin) given 30 to 60 minutes prior to surgery. Aspiration pneumonia can be prevented by good oral hygiene, not lying the patient flat, limiting gastric reflex, not oversedating the patient, good respiratory exercises and early mobilization. As urinary tract infections occur in up to $38 \%$ of patients admitted to hospital with a hip fracture, all patients require urine analysis on admission and use of indwelling Foley catheters should be limited to a maximum of 24 hours (78).

Neumaier et al (79) suggested the use of a serum 


\section{THE JOURNAL OF NUTRITION, HEALTH \& AGING@}

C-reactive protein (CRP) level to monitor persons following surgery to alert physicians to the possibility of post-surgery thromboembolic events, ischemia or infections. On the 2 nd postoperative day, levels of CRP should range from $8 \mathrm{mg} / \mathrm{dl}$ (if nails or screws were used for surgical fixation of the hip) to 16 $\mathrm{mg} / \mathrm{dl}$ (if a hip prosthesis was placed). By the 6th post-surgical day, the CRP should have declined by $4 \mathrm{mg} / \mathrm{dl}$.

\section{Rehabilitation}

Post hip fracture patients have an increase in disabilities at three months and $80 \%$ have not returned to baseline at one year (80). There is emerging evidence that an aggressive long term program including resistance exercise can markedly improve outcomes in older persons following hip fracture $(81,82)$. Importantly it appears that progressive strength training should be started in hospital (83) and carried out into the rehab setting. A 6-week strength training program started after surgery was associated with decreased pain and an increase in 6-minute walk test speed (84). A 12-week resistance program resulted in improvements in gait speed, gait distance and self-rated health (85). A 3-month study of exercise combined with vitamin D improved mortality at 12 months and 4 years following hip fracture (86). Singh et al (87) conducted a 12-month geriatrician-supervised high intensity weight-lifting exercise program following surgical repair of hip fractures. They found a reduction in mortality of $81 \%$ and an $84 \%$ reduction in nursing home admission. In the resistance exercise group, there was an improvement in the performance of basic ADLs and less use of assistive devices. A meta-analysis found that progressive resistance exercise after hip fracture surgery improved mobility, activities of daily living, balance, and lower limb strength and power (88). There is increasing evidence that with appropriately designed programs, an interdisciplinary home rehabilitation program may be as successful as admission to long-term care in a nursing facility (89).

Malafarina et al (90) found that a hydroxymethylbutyrate supplement protected appendicular lean mass. A meta-analysis of oral protein supplements following hip fracture found those taking the supplement had fewer complications, but the evidence was of low quality (91). Additionally, there was no evidence for a reduction in overall mortality. In general, trials evaluating oral nutritional supplements have been poorly designed and of small numbers and few yield clinically significant results.

Patients with hip fracture are highly likely to have dementia (19.2\%) and cognitive impairment (41.8\%) (92). Cognitive impairment is associated with increased mortality following hip fracture (93). There is little information in the literature in regards to how best to rehabilitate persons with dementia and hip fracture (94). At a minimum, physicians need to look for reversible causes of cognitive impairment $(95,96)$ and, where appropriate, enter these patients into cognitive stimulation therapy $(97,98)$. All patients with hip fracture should be screened for cognitive dysfunction using either using the Rapid Cognitive Screen (99), the Saint Louis University Mental Status (SLUMS) examination (100) or the Montreal Cognitive Assessment (101) at some point during their hospital or rehabilitation stay. This is imperative in order to achieve better outcomes because persons with cognitive dysfunction will need help with taking their medicines and adhering to an exercise regimen post-hip fracture.

\section{Prevention of a Second Hip Fracture}

Persons who have had a first hip fracture are at high risk of developing a second hip fracture (102). Prevention requires a focus on reducing fall risk and improving bone health. Approximately a third of falls in older persons are due to syncope caused by either orthostasis, postprandial hypotension or arrhythmias (103-106). These should be individually worked up and excluded. Arrhythmias are frequently undetected and underdiagnosed and the patient may benefit from an implantable arrhythmia monitor (107) in order to improve diagnosis. Involvement in a program of resistance and balance exercises can augment both bone health and fall risk (108). Vision should be improved where possible to minimize falls (108). Similarly, polypharmacy and inappropriate medications should be addressed (109) and drugs that increase hip fracture such as antipsychotics (110) or selective serotonin reuptake inhibitors (111) should be avoided.

For bone health all patients should receive calcium and vitamin D (approximately $1000 \mathrm{IU} /$ day). Total (including dietary) calcium intake should not be greater than $1200 \mathrm{mg}$ per day as higher doses may be associated with myocardial infarction and/or dementia $(112,113)$. Optimal calcium should be taken at night before going to sleep. Yogurt, either fortified or not with supplemental calcium and vitamin D, may be a reasonable alternative (112). Measurement of total 25-hydroxyvitamin D should be avoided as the presence of its binding protein makes its value difficult to determine in different ethnic populations and is not a cost-effective laboratory test (114). Older persons with hip fractures will most likely have osteoporosis and should be treated with bisphosphonates (alendronate or zolendronic acid) or the more expensive denosumab. Bisphosphonates have been shown to decrease the risk of a second hip fracture (115). There is no evidence that bisphosphonates delay bone healing, so they should be started prior to discharge from the hospital. After five years of treatment, a bone mineral density test should be obtained and a decision of whether or not to continue the drug should be made, taking into account the low risk of atypical fractures. Romosozumab is a monoclonal antibody that inhibits sclerostin. A 12 month treatment with this antibody is $38 \%$ more effective at preventing hip fracture than alendronate. However, it does have an increase in cardiovascular events $(116,117)$.

In summary, elderly hip fracture patients receiving care by 


\section{ORTHOGERIATRICS AND HIP FRACTURES}

a collaborative team of geriatricians and orthopedic surgeons have better overall outcomes. Geriatricians can screen patients for conditions, such as dementia, delirium, sarcopenia, polypharmacy, weight loss, and frailty that are likely to confer poorer outcomes and targeted interventions can be put in place to maximize potential recovery and functional status following hip fractures.

\section{References}

1. Lauritzen JB. Hip fractures. Epidemiology, risk factors, falls, energy absorption, hip protectors and prevention. Dan Med Bull 1997;44:155-168.

2. Kanis JA, Oden A, McCloskey EV, Johansson H, Wahl DA, Cooper C; IOF Working Group on Epidemiology and Quality of Life. A systematic review of hip fracture incidence and probability of fracture worldwide. Osteoporosis Int 2012;23:2239 2256.

3. Bhandari M, Swiontkowski M. Management of acute hip fracture. N Engl J Med 2017;377:2053-2062.

4. Devas MB. Geriatric Orthopaedics. Br Med J 1974;1(5900):190-192.

5. Lefroy RB. Treatment of patients with fractured neck of the femur in a combined unit. Med J Aust 1980;2:669-670.

6. Adunsky A, Lerner-Geva L, Blumstein T, Boyko V, Mizrahi E, Arad M. Improved survival of hip fracture patients treated within a comprehensive geriatric hip fracture unit, compared with standard of care treatment. J Am Med Dir Assoc 2011;12:439444.

7. Prestmo A, Hagen G, Sletvold O, et al. Comprehensive geriatric care for patients with hip fractures: A prospective, randomised, controlled trial. Lancet 2015;385:16231633.

8. Grigoryan KV, Javedan H, Rudolph JL. Orthogeriatric care models and outcomes in hip fracture patients: A systematic review and meta-analysis. J Orthop Trauma 2014;28:e49-e55

9. Heyes GJ, Tucker A, Marley D, Foster A. Predictors for 1-year mortality following hip fracture: A retrospective review of 465 consecutive patients. Eur J Trauma Emerg Surg 2017;43:113-119.

10. Cram P, Yan L, Bohm E, Kuzyk P, Lix LM, Morin SN, Majumdar SR, Leslie WD. Trends in operative and nonoperative hip fracture management 1990-2014: A longitudinal analysis of Manitoba administrative data. J Am Geriatr Soc 2017;65:2734.

11. Kamel HK, Iqbal MA, Mogallapu R, Maas D, Hoffmann RG. Time to ambulation after hip fracture surgery: Relation to hospitalization outcomes. J Gerontol A Biol Sci Med Sci 2003:58:1042-1045.

12. Malik AT, Panni UY, Masri BA, Noordin S. The impact of surgeon volume and hospital volume on postoperative mortality and morbidity after hip fractures: A systematic review. Int J Surg 2017;Nov 2. Doi: 10.1016.j.ijsu.2017.10.072 [Epub ahead of print]

13. Moja L, Piatti A, Pecoraro V, Ricci C, Virgili G, Salanti G, et al. Timing matters in hip fracture surgery: Patients operated within 48 hours have better outcomes. A metaanalysis and meta-regression of over 190,000 patients. PLoS One 2012;7(10):e46175.

14. Keil DS, Gross S, Seymour RB, Sims S, Karunakar MA. Mortality after high energy pelvic fractures in patients of age 65 or older. J Orthop Trauma 2017; Sep 29. Doi: 10.1097/BOT.0000000000001041 [Epub ahead of print].

15. Rai SK, Varma R, Wani SS. Does time of surgery and complication have any correlation in the management of hip fracture in elderly and can early surgery affect the outcome? Eur J Orthop Surg Traumatol 2017; Oct 7. Doi: 10.1007/s00590-0172047-0. [Epub ahead of print].

16. Carson JL, Terrin ML, Noveck H, Sanders DW, Chaitman BR, Rhoads GG, et al Liberal or restrictive transfusion in high-risk patients after hip surgery. N Engl J Med 2011;365:2453-2462

17. Gregersen M, Borris LC, Damsgaard EM. Blood transfusion and overall quality of life after hip fracture in frail elderly patients - the transfusion requirements in frail elderly randomized controlled trial. J Am Med Dir Assoc 2015;16:762-766.

18. Morrison RS, Dickman E, Hwang U, Akhtar S, Ferguson T, Huang J, et al. Regiona nerve blocks improve pain and functional outcomes in hip fracture: A randomized controlled trial. J Am Geriatr Soc 2016;64:2433-2439.

19. Guay J, Parker MJ, Griffiths R, Kopp SL. Peripheral nerve blocks for hip fractures: A Cochrane review. Anesth Analg 2017; Oct 4. Doi: 10.1213/ANE.0000000000002489 [Epub ahead of print].

20. Kabboord AD, van Eijk M, Fiocco M, van Balen R, Achterberg WP. Assessment of comorbidity burden and its association with functional rehabilitation outcome after stroke or hip fracture: A systematic review and meta-analysis. J Am Med Dir Assoc 2016; 17:1066.e13-1066.e21

21. Chen KW, Chang SF, Lin PL. Frailty as a predictor of future fracture in older adults A systematic review and meta-analysis. Worldviews Evid Based Nurs 2017;14:282293.
22. Zaslavsky O, Zelber-Sagi S, Gray SL, LaCroix AZ, Brunner RL, Wallace RB, et al Comparison of frailty phenotypes for prediction of mortality, incident falls, and hip fracture in older women. J Am Geriatr Soc 2016;64:1858-1862.

23. Malmstrom TK, Miller DK, Morley JE. A comparison of four frailty models. J Am Geriatr Soc 2014;62:721-726.

24. Morley JE, Vellas B, van Kan GA, Anker SD, Bauer JM, Bernabei R, et al. Frailty consensus: A call to action. J Am Med Dir Assoc 2013;14:392-297.

25. Morley JE, Malmstrom TK, Miller DK. A simple frailty questionnaire (FRAIL) predicts outcomes in middle aged African Americans. J Nutr Health Aging 2012;16:601-608.

26. Woo J, Leung J, Morley JE. Comparison of frailty indicators based on clinical phenotype and the multiple deficit approach in predicting mortality and physical limitation. J Am Geriatr Soc 2012;60:1478-1486.

27. Dent E, Lien C, Lim WS, Wong WC, Wong Ch, Ng TP, Woo J, et al. The AsiaPacific clinical practice guidelines for the management of frailty. J Am Med Dir Assoc 2017;18:564-575.

28. Gleason LJ, Benton EA, Alvarez-Nebreda ML, Weaver MJ, Harris MB, Javedan H. FRAIL questionnaire screening tool and short-term outcomes in geriatric fracture patients. J Am Med Dir Assoc 2017;Aug 30. Doi: 10.1016/j.jamda.2017.07.005 [Epub ahead of print]

29. Morley JE. Developing novel therapeutic approaches to frailty. Curr Pharm Design 2009; 15:3384-3395.

30. McKee A, Morley JE, Matsumoto AM, Vinik A. Sarcopenia: An endocrine disorder? Endocr Pract 2017;23:1140-1149.

31. Yadigar S, Yavuzer H, Yavuzer S, Cengiz M, Huruyen M, Doventas A, Eerdincler DS. Primary sarcopenia in older people with normal nutrition. J Nutr Health Aging 2016;20:234-238.

32. Cederholm T, Morley JE. Sarcopenia: The new definitions. Curr Opin Clin Nutr Metab Care 2015;18:1-4

33. Morley JE, Abbatecola AM, Argiles JM, Baracos V, Bauer J, Bhasin S, Cederholm $\mathrm{T}$, et al. Sarcopenia with limited mobility: An international consensus. J Am Med Dir Assoc 2011;12:403-409.

34. Fielding RA, Vellas B, Evans WJ, Bhasin S, Morley JE, Newman AB, Abellan van Kan G, et al. Sarcopenia: An undiagnosed condition in older adults. Current consensus definition: Prevalence, etiology, and consequences. International Working Group on Sarcopenia. J Am Med Dir Assoc 2011;12:249-256.

35. Morley JE, Anker SD, von Haehling S. Prevalence, incidence, and clinical impact of sarcopenia: Facts, numbers, and epidemiology-update 2014. Sarcopenia Muscle 2015;6:192.

36. Chen LK, Lee WJ, Peng LN, Liu LK, Arai H, Akishita M; Asian Working Group for Sarcopenia. Recent advances in sarcopenia research in Asia: 2016 update from the Asian Working Group for Sarcopenia. J Am Med Dir Assoc 2016;17:767.e1-7.

37. Kim S, Kim M, Won CW. Validation of the Korean Version of the SARC-F questionnaire to assess sarcopenia: Korean frailty and aging cohort study. J Am Med Dir Assoc 2017; doi: 10.1016/j.jamda.2017.07.006.

38. Tanaka S, Kamiya K, Hamazaki N, Matsuzawa R, Nozaki K, Maekawa E, et al. Utility of SARC-F for assessing physical function in elderly patients with cardiovascular disease. J Am Med Dir Assoc 2017;18:176-181

39. Malmstrom TK, Miller DK, Simonsick EM, Ferrucci L, Morley JE. SARC-F: A symptom score to predict persons with sarcopenia at risk for poor functional outcomes. J Cachexia Sarcopenia Muscle 2016;7:28-36.

40. Morley JE. Pharmacologic options for the treatment of sarcopenia. Calcif Tissue Int 2016;98:319-333.

41. Cao L, Morley JE. Sarcopenia is recognized as an independent condition by an International classification of disease, Tenth Revision, Clinical Modivication (ICD10-CM) code. J Am Med Dir Assoc 2016;17:675-677.

42. Anker DS, Morley JE, von Haehling S. Welcome to the ICD-10 code for sarcopenia J Cachexia Sarcopenia Muscle 2016;7:512-514.

43. Harris R, Chang Y, Beavers K, Laddu-Patel D, Bea J, Johnson K, et al. Risk of fracture in women with sarcopenia, low bone mass, or both. J Am Geratr Soc 2017; Sep 27. Doi: 10.111/jgs.15050 [Epub ahead of print].

44. Huo YR, Suriyaarachchi P, Gomez F, Curcio CL, Boersma D, Gunawardene P, et al Comprehensive nutritional status in sarco-osteoporotic older fallers. J Nutr Health Aging 2015;19:474-480.

45. Morley JE. Hip fractures. J Am Med Dir Assoc 2010;11:81-83.

46. Chan DC, Chang CB, Han DS, Hong CH, Hwang JS, Tsai KS, Yang RS. Effects of exercise improves muscle strength and fat mass in patients with high fracture risk: A randomized control trial. J Formos Med Assoc 2017; Oct 26 doi: 10.1016/j. jfma.2017.05.004 [Epub ahead of print].

47. Morley JE. Osteoporosis and fragility fractures. J Am Med Dir Assoc 2011;12:389392

48. Liccini A, Malmstrom TK. Frailty and sarcopenia as predictors of adverse health outcomes in persons with diabetes mellitus. J Am Med Dir Assoc 2016;17:846-851.

49. Morley JE, Malmstrom TK, Rodriguez-Manas L, Sinclair AJ. Frailty, sarcopenia and diabetes. J Am Med Dir Assoc 2014;15:853-859.

50. Morley JE. Weight loss in older persons: New therapeutic approaches. Curr Pharm Des 2007;13:3637-3647.

51. Kellett J, Kyle G, Istiopoulos C, Naunton M. Nutrition screening practice amongst 


\section{THE JOURNAL OF NUTRITION, HEALTH \& AGINGC}

Australian residential aged care facilities. J Nutr Health Aging 2016;20:1040-1044.

52. Vellas B, Villars H, Abellan G, Soto ME, Rolland Y, Guigoz Y, et al. Overview of the MNA - its history and challenges. J Nutr Health Aging 2006;10:456-463.

53. van Wissen J, van Stijn MF, Doodeman HJ, Houdijk AP. Mini nutritional assessment and mortality after hip fracture surgery in the elderly. J Nutr Health Aging 2016;20:964-968

54. Goisser S, Schrader E, Singler K, Bertsch T, Gefeller O, Biber R, Bail HJ, et al Malnutrition according to mini nutritional assessment is associated with severe functional impairment in geriatric patients before and up to 6 months after hip fracture. J Am Med Dir Assoc 2015;16:661-667.

55. van Wissen J, van Stijn MF, Doodeman HJ, Joudijk AP. Mini nutritional assessment and mortality after hip fracture surgery in the elderly. J Nutr Health Aging 2016;20:964-968

56. Reider L, Hawkes W, Hebel JR, D'Adamo C, Magaziner J, Miller R, et al. The association between body mass index, weight loss and physical function in the year following a hip fracture. J Nutr Health Aging 2013;17:91-95.

57. Landi F, Picca A, Clavani R, Marzetti E. Anorexia of Aging: Assessment and Management. Clin Geriatr Med 2017;33:315-323.

58. Morley JE. Anorexia of ageing: A key component in the pathogenesis of both sarcopenia and cachexia. J Cachexia Sarcopenia Muscle. 2017;8:523-526.

59. Sanford AM. Anorexia of aging and its role for frailty. Curr Opin Clin Nutr Metab Care 2017;20:54-60.

60. Morley JE. Anorexia of aging: A true geriatric syndrome. J Nutr Health Aging 2012;16:422-425.

61. Pilgrim AL, Baylis D, Jameson KA, Cooper C, Sayer AA, Robinson SM, Roberts HC. Measuring appetite with the Simplified Nutritional Appetite questionnaire identifies hospitalised older people at risk of worse health outcomes. J Nutr Health Aging 2016;20:3-7.

62. Wilson MM, Thomas DR, Rubenstein LZ, Chibnall JT, Anderson S, Baxi A, Diebold MR, Morley JE. Appetite assessment: Simple appetite questionnaire predicts weight loss in community-dwelling adults and nursing home residents. Am J Clin Nut 2005;82:1074-1081.

63. Brauer C, Morrison RS, Silberzweig SB, et al. The cause of delirium in patients with hip fracture. Arch Intern Med 2000;160:1856-1860.

64. Marcantonio ER, Vlacker JM, Michaels M, et al. Delrium is independently associated with poor functional recovery after hip fracture. J Am Geriatr Soc 2000;48:618-624.

65. Lundstrom M, Olofsson B, Stenvall M, et al. Postoperative delirium in old patients with demoral neck fracture: A randomized intervention study. Aging Clin Exp Res 2007; 19:178-186.

66. Flaherty JH, Morley JE. Delirium in the nursing home. J Am Med Dir Assoc 2013;14:632-634.

67. Scholtens RM, van Munster BC, Adamis D, de Jonghe A, Meagher DJ, de Rooij SE. Variability of delirium motor subtype scale-defined delirium motor subty0pes in elderly adults with hip fracture: A longitudinal study. J Am Geriatr Soc 2017;65:e45e50.

68. Mitchell R, Harvey L, Brodaty H, Draper B, Close J. One-year mortality after hip fracture in older individuals: The effects of delirium and dementia. Arch Gerontol Geriatr 2017;72:135-141.

69. Witlox J, Eurelings LSM, de Jonghe JFM, Kalisvaart KJ, Eikelenboom P, van Gool WA. Delirium in elderly patients and the risk of postdischarge mortality, institutionalization, a nd dementia: A meta-analysis. JAMA 2010;304:443-451.

70. Mangoni AA, van Munster BC, Woodman RJ, de Roij SE. Measures of anticholinergic drug exposure, serum anticholinergic activity, and all-cause postdischarge mortality in older hospitalized patients with hip fractures. Am J Geriatr Psychiatry 2013;21:785-793.

71. Mazzola P, Ward L, Zazzetta S, Broggini V, Anzuini A, Valcarcel B, et al. Association between preoperative malnutrition and postoperative delirium after hip fracture surgery in older adults. J Am Geriatr Soc 2017;65:1222-1228.

72. Iaboni A, Rawson K, Burkett C, Lenze EJ, Flint AJ. Potentially inappropriate medications and the time to full functional recovery after hip fracture. Drugs Aging 2017;34:723-728.

73. Neerland BE, Hall RJ, Seljeflot I, Frihagen F, MacLullich AM, Raeder J, et al. Associations between delirium and preoperative cerebrospinal fluid C-reactive protein, Interleukin-6, and Interleukin-6 receptor in individuals with acute hip fracture. J Am Geriatr Soc 2016;64:1456-1463.

74. Wang Y, Tang J, Zhou F, Yang L, Wu J. Comprehensive geriatric care reduces acute perioperative delirium in elderly patients with hip fractures: A meta-analysis. Medicine (Baltimore). 2017;96:e7361.

75. Wang Y, Tang J, Zhou F, Yang L, Wu J. Comprehensive geriatric care reduces acute perioperative delirium in elderly patients with hip fractures: A meta-analysis. Medicine (Baltimore) 2017;96(26):e7361

76. Flaherty JH, Gonzales JP, Dong B. Antipsychotics in the treatment of delirium in older hospitalized adults: A systematic review. J Am Geriatr Soc 2011;59(Suppl 2):S269-S276

77. Dovjak P, Iglseder B, Mikosch P, Gosch M, Muller E, Pinter G, et al. Treatment and prevention of postoperative complications in hip fracture patients: Infections and delirium. Wien Med Wochenschr 2013;163:448-454.

78. Johansson I, Athlin E, Frykholm L, Bolinder H, Larsson G. Intermittent versus indwelling catheters for older patients with hip fractures. J Clin Nurs 2002;11:651656.

79. Neumaier M, Metak G, Scherer MA. C-reactive protein as a parameter of surgical trauma: CRP response after different types of surgery in 349 hip fractures. Acta Orthop. 2006; 77:788-790.

80. Aarden JJ, van der Esch M, Engelbert RHH, van der Schaaf M, de Rooij SE, Buurman BM. Hip fractures in older patients: Trajectories of disability after surgery. J Nutr Health Aging 2017;21:837-842.

81. Diong J, Allen N, Sherrington C. Structured exercise improves mobility after hip fracture: A meta-analysis with meta-regression. Br J Sports Med 2016;50:346-355.

82. Fiatarone Singh NA, Quine S, Clemson LM, Williams EJ, Williamson DA, Stavrinos TM, Grady JN, et al. Effects of high-intensity progressive resistance training and targeted multidisciplinary treatment of frailty on mortality and nursing home admissions after hip fracture: A randomized controlled trial. J Am Med Dir Assoc 2012;13:24-30.

83. Kronborg L, Bandholm T, Palm H, Kehlet H, Kristensen MT. Effectiveness of acute in-hospital physiotherapy with knee-extension strength training in reducing strength deficits in patients with a hip fracture: A randomised controlled trial. PLoS One 2017; 12:e0179867.

84. Overgaard J, Kristensen MT. Feasibility of progressive strength training shortly after hip fracture surgery. World J Orthop 2013;4:248-258.

85. Sylliaas H, Brovold T, Wyller TB, Bergland A. Prolonged strength training in older patients after hip fracture: A randomised controlled trial. Age Ageing 2012;41:206212.

86. Laiz A, Malouf J, Marin A, Longobardi V, de Caso J, Farrerons J, Casademont J. Impact of 3-monthly vitamin D supplementation plus exercise on survival after surgery for osteoporotic hip fracture in adults patients over 50 years: A pragmatic randomized, partially blinded, controlled trial. J Nutr Health Aging 2017;21:413-420.

87. Singh NA, Quine S, Clemson LM, Williams EJ, Williamson DA, Stavrinos TM, et al. Effects of high-intensity progressive resistance training and targeted multidisciplinary treatment of frailty on mortality and nursing home admissions after hip fracture: A randomized controlled trial. J Am Med Dir Assoc 2012;13:24-30.

88. Lee SY, Yoon BH, Beom J, Ha YC, Lim JY. Effect of lower-limb progressive resistance exercise after hip fracture surgery: A systematic review and meta-analysis of randomized controlled studies. J Am Med Dir Assoc 2017;Oct 12 doi: 10.1016/j. jamda.2017.08.021 [Epub ahead of print].

89. Karlsson A, Berggren M, Gustafson Y, Olofsson B, Lindelof N, Stenvall M. Effects of geriatric interdisciplinary home rehabilitation on walking ability and length of hospital stay after hip fracture: A randomized controlled trial. J Am Med Dir Assoc 2016;17:464.e9-464.e15.

90. Malafarina V, Uriz-Otano F, Malafarina C, Martinez JA, Zulet MA. Effectiveness of nutritional supplementation on sarcopenia and recovery in hip fracture patients. A multi-centre randomized trial. Maturitas 2017;101:42-50.

91. Avenell A, Smith TO, Curtain JP, Mak JC, Myint PK. Nutritional supplementation for hip fracture aftercare in older people. Cochrane Database Syst Rev 2016;11:CD001880

92. Seitz DP, Adunuri N, Gill SS, Rochon PA. Prevalence of dementia and cognitive impairment among older adults with hip fractures. J Am Med Dir Assoc 2011;12:556564 .

93. Gruber-Baldini AL, Hosseini M, Orwig D, Grattan L, Chiles Shaffer N, Hochberg M, Magaziner J. Cognitive differences between men and women who fracture their hip and impact on six-month survival. J Am Geriatr Soc 2017;65:e64-e69.

94. Hall AJ, Lang IA, Endacott R, Hall A, Goodwin VA. Physiotherapy interventions for people with dementia and a hip fracture-a scoping review of the literature. Physiotherapy 2017;103:361-368.

95. Morley JE. New horizons in the management of Alzheimer disease. J Am Med Dir Assoc 2015;16:1-5.

96. Morley JE, Morris JC, Berg-Weger M, Borson S, Carpenter BD, Del Campo N, et al. Brain health: The importance of recognizing cognitive impairment: An IAGG consensus conference. J Am Med Dir Assoc 2015;16:731-739.

97. Berg-Weger M, Tebb S, Henderson-Kalb J, Zubatsky M, Lundy J, Hayden D. Cognitive stimulation therapy: A tool for your practice with persons with dementia? J Am Med Dir Assoc 2015;16:795-796.

98. Morley JE, Cruz-Oliver DM. Cognitive stimulation therapy. J Am Med Dir Assoc 2014;15:689-691.

99. Malmstrom TK, Voss VB, Cruz-Oliver DM, Cummings-Vaughn LA, Tumosa N, Grossberg GT, Morley JE. The Rapid Cognitive Screen (RCS): A point-ofcare screening for dementia and mild cognitive impairment. J Nutr Health Aging 2015;19:741-744.

100. Tariq SH, Tumosa N, Chibnall JT, Perry MH 3rd, Morley JE. Comparison of the Saint Louis University mental status examination and the mini-mental state examination for detecting dementia and mild neurocognitive disorder-a pilot study. Am J Geriatr Psychiatry 2006;14:900-910.

101. Shaik MA, Chan QL, Xu J, Xu X, Hui RJ, Chong SS, Chen CL, Dong Y. Risk factors of cognitive impairment and brief cognitive tests to predict cognitive performance determined by a formal neuropsychological evaluation of primary health care patients. J Am Med Dir Assoc 2016;17:343-347.

102. Blain H, Masud T, Dargent-Molina P, martin FC, Rosendahl E, van der Velde N, et 


\section{ORTHOGERIATRICS AND HIP FRACTURES}

al. A comprehensive fracture prevention strategy in older adults: The European Union Geriatric Medicine Society (EUGMS) statement. J Nutr Health Aging 2016;20:647652.

103. Morley JE. Frailty, falls, and fractures. J Am Med Dir Assoc 2013;14:149-151

104. Morley JE. Syncope. J Am Med Dir Assoc 2013;14:311-312.

105. Trahair LG, Horowitz M, Jones KL. Postprandial hypotension: A systematic review. J Am Med Dir Assoc 2014;15:394-409.

106. Vinik AI, Camacho P, Reddy S, Valencia WM, Trence D, Matsumoto AM, Morley JE. Aging, diabetes, and falls. Endocr Pract 2017;23:1117-1139.

107. Morley JE. Syncope. J Am Med Dir Assoc 2013;14:311-312.

108. Tricco AC, Thomas SM, Veroniki AA, Hamid JS, Cogo E, Strifler L, et al. Comparisons for interventions for preventing falls in older adults: A systematic review and meta-analysis. JAMA 2017;318:1687-1699.

109. Rolland Y, Morley JE. Frailty and polypharmacy. J Nutr Health Aging 2016;20:645646.

110. Bakken MS, Schjott J, Engeland A, Engesaeter LB, Ruths S. Antipsychotic drugs and risk of hip fracture in people aged 60 and older in Norway. J Am Geriatr Soc 2016;64:1203-1209.

111. Hung SC, Lin CH, Hung HC, Lin CL, Lai SW. Use of selective serotonin reuptake inhibitors and risk of hip fracture in the elderly: A case-control study in Taiwan. J Am Med Dir Assoc 2017;18:350-354.
112. Bonjour JP, Benoit V, Atkin S, Walrand S. Fortification of yogurts with vitamin $\mathrm{D}$ and calcium enhances the inhibition of serum parathyroid hormone and bone resorption markers: A double blind randomized controlled trial in women over 60 living in a community dwelling home. J Nutr Health Aging 2015;19:563-569.

113. Michaelsson K, Melhus H, Warensjo Lemming E, Wolk A, Byberg L. Long term calcium intake and rates of all cause and cardiovascular mortality: Community based prospective longitudinal cohort study. BMJ 2013;246:f228. Doi: 10.1136/bmj.f228.

114. Powe CE, Evans MK, Wenger J, Zonderman AB, Berg AH, Nalls M, Tamez H, et al. Vitamin D-binding protein and vitamin D status of black Americans and white Americans. N Engl J Med 2013;369:1991-2000.

115. Nordstrom P, Toots A, Gustafson Y, Thorngren KG, Hommel A, Nordstrom A. Bisphosphonate use after hip fracture in older adults: A nationwide retrospective cohort study. J Am Med Dir Assoc 2017;18:515-521.

116. Cosman F, Crittenden DB, Adachi JD, Binkley N, Czerwinski E, Ferrari S, et al Romosozumab treatment in postmenopausal women with osteoporosis. N Engl J Med 2016;375:1532-1543.

117. Saag KG, Petersen J, Brandi ML, Karaplis AC, Lorentzon M, Thomas T, et al Romosozumab or alendronate for fracture prevention in women with osteoporosis. N Engl J Med 2017;377:1417-1427. 